\title{
As the world grows: contraception in the 21st century
}

\author{
R. John Aitken, ${ }^{1}$ Mark A. Baker, ${ }^{1}$ Gustavo F. Doncel, ${ }^{2}$ \\ Martin M. Matzuk, ${ }^{3}$ Christine K. Mauck, ${ }^{2}$ and Michael J.K. Harper² \\ ${ }^{1}$ Discipline of Biological Sciences and ARC Centre of Excellence in Biotechnology and Development, University of Newcastle, \\ Callaghan, New South Wales, Australia. ${ }^{2}$ CONRAD, Eastern Virginia Medical School, Arlington, Virginia, USA. \\ ${ }^{3}$ Departments of Pathology, Molecular and Cellular Biology, and Molecular and Human Genetics, Baylor College of Medicine, Houston, Texas, USA.
}

\begin{abstract}
Contraceptives that are readily available and acceptable are required in many poorer countries to reduce population growth and in all countries to prevent maternal morbidity and mortality arising from unintended pregnancies. Most available methods use hormonal steroids or are variations of barrier methods. Reports from several fora over the last 12 years have emphasized the number of unwanted pregnancies and resultant abortions, which indicate an unmet need for safe, acceptable, and inexpensive contraceptive methods. This unmet need can be assuaged, in part, by development of new nonhormonal contraceptive methods. This Review addresses the contribution that the "omic" revolution can make to the identification of novel contraceptive targets, as well as the progress that has been made for different target molecules under development.
\end{abstract}

\section{Retrospect}

More than 700,000 maternal deaths, most in the developing world and related to causes associated with unintended pregnancies, occurred between 1995 and 2000; more than 400,000 of these deaths resulted from unsafe abortions (1). This indicates that existing contraceptives are either not available or not adequate. The need for safe and effective contraceptives has also been highlighted in two Institute of Medicine reports, published in 1996 and 2004 (2, 3). The 1996 report concluded that there is a need for contraceptive research and development; that contraceptive research and development need to be revitalized; and that there are scientific prospects that could revitalize the field (2). The 2004 report was more focused and addressed only two issues - facilitating translational research from contraceptive target identification to initial clinical studies and developing strategies for research success (3). Specific recommendations in the 2004 report were to utilize new "omic" technologies to assist in contraceptive target identification and validation; to improve the translational process with financial support and use of surrogate markers; to focus on druggable targets and tissue specificity; to seek to identify a priori rather than by serendipity other health benefits that the drugs might have in addition to contraception (e.g., prevention of breast and prostate carcinoma); and to recruit industry and a new generation of scientists to the cause.

There have been some advances in contraceptive development in the years since the first contraceptive revolution provided by the oral contraceptive (OC) pill regimen (4-6), e.g., the development of Copper T380A and levonorgestrel-releasing (LNG-releasing) intrauterine devices (IUDs) (7-9). However, most of the advances have, in fact,

Nonstandard abbreviations used: Eppin, epididymal protease inhibitor; FSH, follicle-stimulating hormone; GAPDHS, GAPDH, spermatogenic; hCG, human chorionic gonadotropin; IUD, intrauterine device; LH, luteinizing hormone; LIF, leukemia inhibitory factor; LIFR, LIF receptor; LNG, levonorgestrel; OC, oral contraceptive; OR, odorant receptor; PC6, proprotein convertase 6; PEGylated, conjugated to polyethylene glycol; PRM, progesterone receptor modulator; RAR $\alpha$, retinoic acid receptor- $\alpha$; TEX14, testis-expressed gene 14 .

Conflict of interest: M.J.K. Harper has stock holdings in GlaxoSmithKline and Procter \& Gamble. M.J.K. Harper, G.F. Doncel, and C.K. Mauck work for CONRAD, which has received support from the Bill and Melinda Gates Foundation. The remaining authors have declared that no conflict of interest exists.

Citation for this article: J. Clin. Invest. 118:1330-1343 (2008). doi:10.1172/JCI33873. been developments of new delivery methods for existing and novel hormonal steroids, mostly acting by inhibition of ovulation. This has, to a large extent, been conflated by the fact that the length of time required to develop new methods has been substantially longer than many investigators and other experts in the field estimated $(10,11)$. Other problems hampering the development of new contraceptive methods include the fact that within the last two years, most large pharmaceutical companies involved in fertility regulation have withdrawn from the contraceptive research and development field. Thus, the outlook for the development of new contraceptives is grim and will depend solely on the public sector, where funding is also more constrained than in 1996. Realistically, development of a new contraceptive agent from target validation to the pivotal clinical trials can take up to $15-20$ years and cost $\$ 100$ million or more. These facts have been responsible for donor fatigue and some means has to be devised to reenergize the field (12).

Indeed, progress in the contraceptive development arena has been so poor that a recent report by the United Kingdom All Party Parliamentary Group on Population, Development and Reproductive Health (13) has concluded that the UN Millennium Development Goals cannot be met given the levels of population growth in the poorest countries. The Parliamentary Report also clearly indicated that claims advanced to refute the need for more contraceptive development - that birth rates are falling and good contraceptive methods are available now (14) - are not correct for many poor countries. In their 2004 article, Collumbien et al. (15) concluded that globally, maternal conditions stemming from unwanted births resulted in a loss of 98,000 lives and 4.5 million disability-adjusted life years. However, regional differences were large, with the effects being especially high in eastern and southern Africa. Non-use of available contraceptives is responsible for $90 \%$ of these unwanted births. A recent report from the Guttmacher Institute concluded that unmet contraceptive need ranges from $10 \%-12 \%$ in developing countries and that health effects and inconvenience are the main reasons for this non-use (16). For many women, existing contraceptives are therefore not acceptable or not available and thus in many cases are not used. Further, the importance of developing a diverse range of contraceptives acceptable to individual preferences is highlighted by the observa- 
tion that women in the United States who are neutral about or dissatisfied with their contraceptive method are more than three times more likely than women satisfied with their contraceptive method to have a gap of at least one month in a 12-month period during which they use no contraception despite being sexually active (17). There is very unlikely ever to be a contraceptive "silver bullet" that will suit all men or all women, irrespective of whether they are healthy and at what stage of their reproductive life cycle they are. This reinforces the need to develop various new (preferably nonhormonal) methods that are easy to use, safe, inexpensive, and sufficiently diverse in their methodology to be acceptable to individuals of different cultures and with different medical needs. Contraceptives that also provide protection against sexually transmitted infections, especially HIV, are urgently needed, as shown by the high rates of pregnancy and cervical infections in young sex workers in Madagascar (18).

To achieve these goals, it will be necessary to once again place population and family planning at the center of global efforts to improve reproductive health and fight poverty (19). As we discuss in this Review, we therefore need to know where we are: what is in the clinic, what is in the pipeline and at what stage, what needs to be done, and what are the key challenges? To close the gap between what contraceptive methods are available and what are needed, attention has turned to the new science of the omic revolution, which permits the identification of novel targets for contraception.

\section{Contraceptives in the clinic and in clinical trials}

Contraceptive methods for men and women can be divided into four main categories: steroidal methods, sterilization, vaccines, and barrier methods (physical and chemical). Tables 1-3 show contraceptive methods that have been recently approved and methods that are still in clinical trials.

Steroidal methods for women. Steroidal methods of contraception used by women prevent pregnancy by interfering with ovulation and the normal menstrual cycle (Figure 1). They can be oral or nonoral and can consist of an estrogen component combined with a progestin component or a progestin alone. The estrogen component of the contraceptive inhibits the release of follicle-stimulating hormone (FSH) from the anterior pituitary gland, thereby preventing follicular maturation. The progestin component inhibits the release of luteinizing hormone (LH) from the anterior pituitary, thereby preventing ovulation. The progestin also thickens cervical mucus, which impedes the movement of sperm into the uterus. Traditionally, combined OCs are taken for 21 consecutive days followed by 7 days of either no pills or placebo pills. When taken correctly and consistently, combined and progestin-only OCs are more than $99 \%$ effective at preventing pregnancy (20).

Recent modifications to OC regimens center on making the products more "forgiving" of incorrect use and on reducing uterine bleeding. The latter is usually an advantage in terms of convenience, but it can be medically important in women at risk for anemia. Both aims can be accomplished by eliminating the days on which no active pills are taken. This regimen avoids "escape ovulation," which can happen if a new pack of OCs is not started on time, and reduces the number of periods that women experience while taking OCs (21). Three OC products with modified regimens have entered the market in recent years: Seasonale, Seasonique, and Lybrel (Table 1).

OCs containing LNG can also be taken immediately after intercourse that was otherwise unprotected from conception: so-called emergency contraception. When taken within 72 hours of unprotected sex, they reduce the chance of pregnancy by $75 \%-89 \%$. The main mechanism of action of such OCs is interference with ovulation, either by preventing or delaying luteal function (22). Steroidal antiprogestins are also effective (Table 1) (23).

Although efforts in the United States and other countries have centered on making emergency contraception more readily available, some new products are also being studied as alternatives to traditional steroidal methods in the hope that they have fewer side effects or are active for a longer period of time after unprotected intercourse (Table 1). For example, meloxicam is a COX-2 inhibitor that prevents follicular rupture and is being studied as an alternative emergency contraceptive that might expand the window during which emergency contraception is effective by 24 hours over current treatments $(24,25)$.

Nonoral forms of contraceptive steroids have been developed to eliminate the need for daily dosing. These include patches, vaginal rings, implants, injectables, and steroid-releasing IUDs (Table 1). There have been concerns about an increased risk of venous thromboembolic events for users of patch and ring approaches to nonoral steroidal contraceptives (26-28). However, these have not resulted in any of the approaches being withdrawn from the market, only labeling changes. The 6-rod implant Norplant, which was voluntarily withdrawn from the US market in 2002, has been replaced with better systems, Jadelle (two rods) and Implanon, a one-rod implant, and others are under study. Injectable steroidal contraceptives include progestin-only methods as well as combinations of progestin and estrogen. Progestin-only methods, given i.m. every 2-3 months, include medroxyprogesterone acetate and norethisterone enanthate. Combination injectables are available in at least 5 formulations and are given monthly. Although the progestin-only medroxyprogesterone acetate injectable DepoProvera has been used worldwide for decades, there are concerns about its effect on bone mineral density (29-31). Mirena is an intrauterine system releasing $20 \mu \mathrm{g} / \mathrm{d}$ of LNG, which has proved to be highly effective and to have other health benefits, such as reduced uterine bleeding $(9,32)$.

Steroidal methods for men. Hormonal methods of male fertility regulation are based on the fact that exogenous testosterone can suppress spermatogenesis. This suppression is primarily achieved through feedback inhibition on the hypothalamic-pituitary-testicular axis, resulting in decreased release of pituitary gonadotropins FSH and LH. This then causes disruption of normal Sertoli cell function and endogenous testosterone production by testicular Leydig cells, respectively $(33,34)$. Normal sperm production is maintained by high intratesticular testosterone concentrations, and thus very low levels of intratesticular testosterone result in few or no detectable sperm, irrespective of circulating testosterone levels (35). Progestins also inhibit gonadotropin production and perhaps also exert a direct effect on the testis, thus providing a synergistic action (36). Numerous combinations of androgen and progestin have been tested in small sperm suppression studies; only one contraceptive effectiveness trial of a combination has been conducted (37).

A recent review of 30 studies of steroidal contraception in men found wide variation in the proportion of men who achieved azoospermia (38). The WHO has published the results of a large multicenter contraceptive study in which healthy men received $200 \mathrm{mg}$ testosterone enanthate weekly by intramuscular injection for 6 months (Table 2$)(35,39)$. The low pregnancy rates were promising, but the frequent injection schedule was a problem. An 


\section{Table 1}

Examples of steroid-based contraceptive products for women recently introduced in the clinic and in clinical trials

\begin{tabular}{|c|c|}
\hline $\begin{array}{l}\text { Product } \\
\text { OCs }\end{array}$ & Method of use \\
\hline Seasonale & $\begin{array}{l}84 \text { tablets containing EE (an estroge } \\
\text { LNG (a progestin) and } 7 \text { placebo }\end{array}$ \\
\hline Seasonique & $\begin{array}{l}84 \text { tablets containing EE and LNG an } \\
7 \text { tablets containing } 10 \mu \mathrm{gEE}\end{array}$ \\
\hline Lybrel & $\begin{array}{l}28 \text { tablets containing } 90 \mu \mathrm{g} \text { of } \mathrm{LNG} \\
20 \mu \mathrm{g} \text { of } \mathrm{EE} \text {, to be taken continuo }\end{array}$ \\
\hline \multicolumn{2}{|c|}{ Emergency contraceptives } \\
\hline CDB-2914: VA-2914 & $\begin{array}{l}50 \mathrm{mg} \text { taken within } 5 \text { days of } \\
\text { unprotected intercourse }\end{array}$ \\
\hline Meloxicam & $\begin{array}{l}\text { Dosage to be determined. Could be } \\
\text { used alone or with LNG (24) }\end{array}$ \\
\hline
\end{tabular}

\section{Nonoral steroidal contraceptives}

Ortho Evra patch Releases $20 \mu \mathrm{g}$ of EE and $150 \mu \mathrm{g}$ norelgestromin daily

\begin{tabular}{|c|c|}
\hline NuvaRing & $\begin{array}{l}\text { Releases } 150 \mu \mathrm{g} \text { etonogestrel } \\
\text { and } 15 \mu \mathrm{g} \mathrm{EE} \mathrm{per} \mathrm{day}\end{array}$ \\
\hline Nestorone ring & $\begin{array}{l}\text { Releases } 150 \mu \mathrm{g} \text { nestorone (a synthetic } \\
\text { progestin not active when taken orally) } \\
\text { and } 15 \mu \mathrm{g} \text { EE per day }\end{array}$ \\
\hline Nestorone spray & $\begin{array}{l}\text { Dosage to be determined; will be } \\
\text { combined with estrogen }\end{array}$ \\
\hline Nestorone rod & $\begin{array}{l}\text { Single-rod uterine implant releasing } \\
\text { nestorone for } 2 \text { years; daily } \\
\text { transdermal spray }\end{array}$ \\
\hline Implanon & $\begin{array}{l}\text { Single-rod uterine implant that contains } 68 \\
\text { mg of etonogestrel released over } 3 \text { years }\end{array}$ \\
\hline Depo-Provera & $150 \mathrm{mg}$ i.m. every 3 months \\
\hline
\end{tabular}

Effect and/or benefit

Menstrual periods are reduced from 1 per month to 1 every 3 months

Menstrual periods are reduced from 1 per month to 1 every 3 months. The 7 tablets containing $10 \mu \mathrm{g}$ EE reduce breakthrough bleeding

No scheduled bleeding

Synthetic selective PRM that binds the progesterone receptor but has no progestational activity

Nonsteroid that might expand the window during which emergency contraception is effective by 24 hours. Prevents follicular rupture even after the LH surge (25)

Prevents the need for daily dosing. In 2005 , FDA required a new bolded warning that users are exposed to about $60 \%$ more total estrogen in their blood than women taking a daily $\mathrm{OC}$ containing $35 \mu \mathrm{g}$ of estrogen because 1 of 2 studies found an increased risk of venous thromboembolic events $(26,28)$

Prevents the need for daily dosing. In 2005, FDA required labeling to reflect an increased risk of thromboembolic and thrombotic disease

Prevents the need for daily dosing

Avoids side effects common in oral dosing

Prevents the need for daily dosing

Prevents the need for daily dosing

Prevents the need for daily dosing. In 2004 , FDA required "black-box" warning regarding BMD as 2 studies suggested users could lose significant BMD (29-31). FDA warning states Depo-Provera should not be used for more than 2 years unless other contraceptives are inadequate. Other studies have generated different results, and the WHO does not advise restrictions.

Prevents the need for daily dosing. Thought to not affect BMD as Depo-Provera does

Less pain and bleeding than copper IUDs. Approved for only 5 years. Can cause steroidrelated side effects such as acne and ovarian cysts $(7,9,32)$.
Stage of development

In the clinic since 2003

In the clinic since 2006

In the clinic since 2007

Phase III clinical trials (23)

Inexpensive and widely available OTC; could be available OTC for emergency contraception

In the clinic since 2001

In the clinic since 2005

Phase 3 clinical trial

Early trials

Phase II trials of implant completed

In the clinic since 2006

In the clinic since 1992

Early trials planned

In the clinic since 2000
Mirena intrauterine Contains $52 \mathrm{mg}$ LNG; releases $20 \mu \mathrm{g} / \mathrm{d}$ and is to be tested in combination with norethisterone enanthate in a contraceptive effectiveness study (Table 2). improved formulation of testosterone undecanoate given once every two months suppressed spermatogenesis in a pilot study (40)

$\mathrm{BMD}$, bone mineral density; EE, ethinyl estradiol; OTC, over the counter 


\section{Table 2}

Examples of steroid-based contraceptive products for men recently introduced in the clinic and in clinical trials

\begin{tabular}{|c|c|c|c|}
\hline Product & Method of use & Effect and/or benefit & Stage of development \\
\hline $\begin{array}{c}\text { Testosterone } \\
\text { enanthate }\end{array}$ & $\begin{array}{l}200 \mathrm{mg} \text { injected i.m. } \\
\text { weekly for } 6 \text { months }\end{array}$ & $\begin{array}{l}\text { Azoospermia in } 65 \% \text { of men in } 6 \text { months; only } 1 \text { pregnancy in } 1,486 \\
\text { months (35). Recovery of sperm counts after about } 4 \text { months of no } \\
\text { treatment (35). Second study determined that among men who } \\
\text { achieved oligospermia, only } 4 \text { pregnancies occurred in } 49.5 \\
\text { person-years of use, and among azoospermic men, there were no } \\
\text { pregnancies in } 230.4 \text { person-years of use (39). Frequent injection } \\
\text { schedule caused } 5 \% \text { to discontinue (39) }\end{array}$ & Proof of principle \\
\hline $\begin{array}{l}\text { Testosterone } \\
\text { undecanoate }\end{array}$ & $\begin{array}{l}1,000 \mathrm{mg} \text { testosterone } \\
\text { undecanoate and } \\
200 \mathrm{mg} \text { norethisterone } \\
\text { enanthate given in } 2 \\
\text { separate i.m. injections } \\
\text { every } 8 \text { weeks }\end{array}$ & $\begin{array}{l}\text { Suppressed spermatogenesis (40). If found to be an effective } \\
\text { contraceptive, both steroids will be formulated in } 1 \text { injection, } \\
\text { which should increase acceptability }\end{array}$ & $\begin{array}{l}\text { Contraceptive } \\
\text { effectiveness study } \\
\text { about to start }\end{array}$ \\
\hline
\end{tabular}

Sterilization. Nonsurgical (transcervical) methods of female sterilization offer lower cost, fewer complications, and faster recovery than surgical sterilization. However, the need for hysteroscopy affects their utility in developing countries (41). Products that can be used to achieve nonsurgical sterilization of women include liquids, coils, plugs, and chemical irritants (Table 3). For males, recent alternatives to vasectomy are aimed at improved reversibility (42) and include implants and gels (Table 3) (43-45).

Contraceptive vaccines. In the 1980 s, there was much activity in the area of contraceptive vaccines, targeting antigens such as human chorionic gonadotrophin (hCG), FSH, and gonadotrophin-releasing hormone (GnRH) (46). However, due to lack of progress and funding as well as safety concerns, only a low level of effort on the hCG vaccine for women continues. This vaccine comprises a formulation of two novel poly(lactic-co-glycolic acid) microspheres that deliver a synthetic hCG peptide cosynthesized with a T cell epitope from tetanus toxoid (47). Contraceptive vaccines for men are still very much in the basic science phase, with the recently discovered epididymal protease inhibitor (Eppin) (48) providing a potential target antigen.

Barrier methods. Barrier methods are of two kinds: mechanical and chemical (Table 3). Often they are used together, as in the case of a diaphragm used with a spermicide. Efforts to improve mechanical barriers such as diaphragms and cervical caps have focused on easier fitting, ideally with one size that fits all users, use of nonlatex materials to avoid the problem of latex allergies, and easier insertion and removal. Traditionally used for contraception, cervical barriers are now being studied as a method to prevent sexually transmitted infections and HIV (49). However, a recent study in 4,500 women in South Africa and Zimbabwe showed that provision of a latex diaphragm with lubricant gel plus condoms provided no greater protection against infection with HIV than provision of condoms alone (50).

The Reality female condom has been in use to some degree in many countries since 1992 (Table 3) (51-54). Limitations to its more widespread use center on cost and use characteristics. Reuse studies have been done to address the former and, although reuse is not recommended, the WHO has developed a protocol for cleaning female condoms with a bleach solution, permitting reuse five times. Washing with soap and water is also effective (55). Use of synthetic latex should also reduce costs. Problems of acceptability have led to a wide variety of new designs. At least two are variations on a replaceable-condom-in-a-panty, which is felt to have a more acceptable appearance than the outer ring of the original female condom. Others include the Reddy latex female condom and PATH's woman's condom (Table 3) (56).

Nonoxynol-9 is a moderately effective spermicidal chemical contraceptive, but frequent use has been suggested to increase the risk of becoming infected with HIV compared with placebo (57). This negative effect might be due to disruption of the integrity of the cervicovaginal mucosa and induction of an immunoinflammatory response facilitating infection with $\operatorname{HIV}(58,59)$. Recent work has focused on alternative products, most of which display both contraceptive and microbicidal activity without mucosal irritating properties (Table 3) (60). Cellulose sulfate $6 \%$ vaginal gel was effective as a vaginal contraceptive but failed to protect women against HIV infection (61-63).

\section{How the omic revolution has had an impact on contraceptive development}

The last 25 years have seen remarkable developments in the areas of genomics and proteomics as well as the generation of transgenic models for the study of reproduction (64). Several mammalian genomes, including the human, rhesus macaque, mouse, and rat, have been almost completely sequenced. With new advances in DNA sequencing technology, multiple genomes are being sequenced each year at amazing speed. Transcriptomes of individual cells, tissues, and organisms have been quickly deposited into databases and include not only messenger, transfer, and ribosomal RNAs, but also microRNAs, siRNAs, and PIWI-interacting RNAs. In parallel with these advances, new technologies permitting the large-scale characterization of complex protein mixtures (proteomics), and the integration of these proteins into known pathways (systems biology) have had a major impact on the potential for contraceptive development, especially in males (65). In addition, the advent of metabolomic technologies enables us to profile the metabolic processes that are critical to reproductive function. Integration of these metabolic data with the proteome and transcriptome will revolutionize our understanding of how the reproductive system works and, at the same time, identify and characterize key targets for novel contraceptives.

Challenges to using genomic information. Recommendation 1 of the 2004 Institute of Medicine report (3) was to "Identify and characterize all genes and proteins uniquely or preferentially expressed in the 
Table 3

Examples of nonsteroidal contraceptive products recently introduced in the clinic and in clinical trials

\begin{tabular}{|c|c|c|c|}
\hline Product & Method of use & Effect and/or benefit & Stage of development \\
\hline \multicolumn{4}{|c|}{ Nonsurgical female sterilization } \\
\hline Ovabloc & $\begin{array}{l}\text { Liquid siloxane is inserted } \\
\text { into the tubal orifice, then } \\
\text { polymerizes into a plug }\end{array}$ & & Not approved \\
\hline Essure & $\begin{array}{l}\text { A small metal coil is placed } \\
\text { into each fallopian tube } \\
\text { through the cervix using a } \\
\text { catheter. Once in place, the } \\
\text { device elicits tissue growth } \\
\text { to form an occlusion }\end{array}$ & & In the clinic since 2002 \\
\hline Quinacrine & $\begin{array}{l}\text { Chemical tubal occlusion. } \\
7 \text { pellets placed high in } \\
\text { the uterus using a modified } \\
\text { IUD inserter; these dissolve } \\
\text { and cause scarring of the } \\
\text { opening of the fallopian tube }\end{array}$ & & $\begin{array}{l}\text { Abandoned due to } \\
\text { carcinogenicity } \\
\text { concerns }(171,172)\end{array}$ \\
\hline \multicolumn{4}{|l|}{ Vasal occlusion } \\
\hline Intravas device (SHUG) & $\begin{array}{l}\text { Two types: a pair of } \\
\text { silicone plugs and urethane } \\
\text { tube lined with nylon sieve }\end{array}$ & $\begin{array}{l}\text { Trap sperm but allow fluid in the vas to pass through, reducing } \\
\text { likelihood of congestive epididymitis. Double-plug design did } \\
\text { not completely block sperm transport through the epididymis, } \\
\text { failing in } 3 \text { of } 30 \text { men (43) }\end{array}$ & Not approved \\
\hline RISUG & $\begin{array}{l}\text { Styrene maleic anhydride } \\
\text { in a solvent vehicle of } \\
\text { dimethyl sulfoxide gel } \\
\text { injected into the vas }\end{array}$ & $\begin{array}{l}\text { Partially occludes vas and has direct toxic effect on sperm for at } \\
\text { least } 1 \text { year (44). May be reversible with second injection (45) }\end{array}$ & $\begin{array}{l}\text { Phase III clinical trials } \\
\text { in India }\end{array}$ \\
\hline \multicolumn{4}{|l|}{ Barrier methods } \\
\hline SILCS & Silicone cervical diaphragm & Available in 1 size believed to fit most women $(173,174)$ & $\begin{array}{l}\text { Phase III contraceptive } \\
\text { effectiveness trial }\end{array}$ \\
\hline FC2 & $\begin{array}{l}\text { Female condom made of } \\
\text { synthetic latex }\end{array}$ & $\begin{array}{l}\text { Should cost less than original female condom }(52) \text {. } \\
\text { Performance and acceptability of original female condom and } \\
\text { FC2 were comparable in South African trial }(53,54) \text {. }\end{array}$ & $\begin{array}{l}\text { Has received CE marking } \\
\text { for product and } \\
\text { manufacturing but is } \\
\text { not approved in US }\end{array}$ \\
\hline $\begin{array}{l}\text { Reddy latex } \\
\text { female condom }\end{array}$ & $\begin{array}{l}\text { Soft polyurethane sponge } \\
\text { aids insertion }\end{array}$ & $\begin{array}{l}\text { Appeared more acceptable than original female condom } \\
\text { in Indian trial (56). }\end{array}$ & Not approved in US \\
\hline $\begin{array}{l}\text { PATH's woman's } \\
\text { condom }\end{array}$ & $\begin{array}{l}4 \text { small foam dots on outside } \\
\text { of inner ring adhere to vagina } \\
\text { to hold condom in place }\end{array}$ & $\begin{array}{l}\text { Closed end of condom is gathered into gelatin-based capsule } \\
\text { that facilitates insertion, then dissolves after use }\end{array}$ & Phase I trial completed \\
\hline UsherCell & $\begin{array}{l}6 \% \text { cellulose sulfate vaginal } \\
\text { gel to be inserted before } \\
\text { intercourse }\end{array}$ & $\begin{array}{l}\text { Inhibits sperm function and egg binding (61). Has shown } \\
\text { promise in contraceptive efficacy trials (62), but } 2 \text { HIV } \\
\text { prevention trials were stopped for lack of efficacy and possible } \\
\text { increased risk of infection, which in the final intent-to-treat } \\
\text { analysis proved not significant (63) }\end{array}$ & Development on hold \\
\hline BufferGel & $\begin{array}{l}\text { Carbopol-based gel to be } \\
\text { inserted before intercourse }\end{array}$ & $\begin{array}{l}\text { Immobilizes spermatozoa by lowering pH (175). Has shown } \\
\text { promise in contraceptive efficacy trials (176) and is being } \\
\text { evaluated for HIV prevention }\end{array}$ & $\begin{array}{l}\text { Phase III contraceptive } \\
\text { trial of BufferGel with } \\
\text { diaphragm completed; } \\
\text { phase III HIV } \\
\text { prevention trial } \\
\text { underway }\end{array}$ \\
\hline
\end{tabular}

RISUG, Reversible Inhibition of Sperm Under Guidance; CE marking, mandatory conformity mark on products placed on the single market in the European Economic Area (EEA).

testis, ovary, and reproductive tissues; and define the genetic and protein networks in cells relevant to reproduction, including construction of a protein interaction map for the sperm and the egg." Despite all the progress in generating omic information, there are more than 1,000 reproductive tissue-expressed genes for which there is minimal information available about the full-length mRNA, the protein product of the gene, and the protein localization (66-68). The actual number might actually run considerably higher, since published data indicate that $4 \%$ of the mammalian genome (i.e., more than 2,300 genes) comprises genes that are specifically expressed in the male germline during or after the completion of meiosis (66). Proteomic analysis of human, rat, and mouse spermatozoa has demonstrated that over 1,000 proteins are present in each of these cell types (65). Since many of the proteins are considered "novel" (i.e., do not con- 


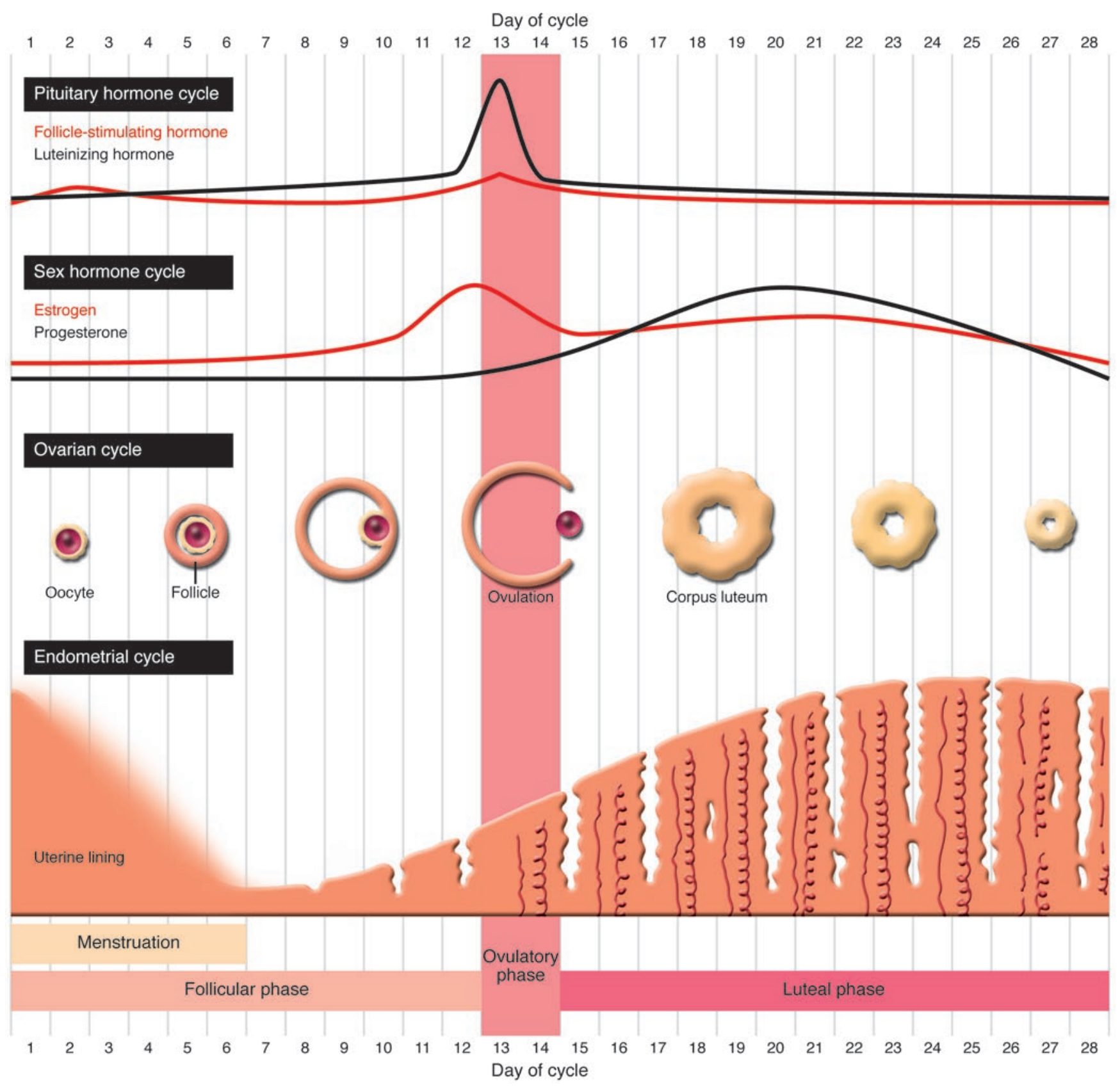

\section{Figure 1}

The human female menstrual cycle. The human female menstrual cycle is divided into several phases, which vary in length among women and among cycles; average times are indicated. The first phase of the menstrual cycle is the follicular phase, and it begins the day that menstrual bleeding starts. A decrease in the levels of estrogen and progesterone triggers the top layers of the thickened endometrium to break down and be shed, resulting in bleeding. Concomitant with this, levels of FSH increase very slightly, stimulating the development of several oocyte-containing follicles. FSH levels subsequently decrease and only one or two follicles continue to develop. The developing follicles release estrogen, and this initiates thickening of the endometrium, something that continues throughout the rest of the menstrual cycle. The second phase of the menstrual cycle is the ovulatory phase. It begins at approximately day 13, when levels of LH and FSH increase dramatically; levels of estrogen also peak at this time, and levels of progesterone begin to increase. The high levels of LH stimulate ovulation. The final phase of the menstrual cycle is the luteal phase. During this phase, levels of LH and FSH decrease and the ruptured follicle forms the corpus luteum, which produces large amounts of progesterone. Progesterone modifies the endometrium so that it is receptive to implantation of an embryo if fertilization has occurred. In the absence of fertilization, the corpus luteum degenerates and the loss of progesterone production, combined with decreased levels of estrogens, initiates a new menstrual cycle.

tain domains that match known proteins), protein localization, protein interaction networks, and spatiotemporal expression and func- tion cannot be inferred, meaning that they remain to be explored as potential contraceptive targets. 
A common way to determine the function of a gene is to generate a knockout mouse. If a knockout of a gene in mice results in a fertility defect (and more importantly, infertility), then this is a proof of principle that blocking the function of the protein product with a small molecule inhibitor would have a contraceptive effect. Indeed, recommendation 3 of the 2004 Institute of Medicine report (3) was to "Validate existing and emerging contraceptive targets by using forward and reverse genetic approaches with model organisms." More than 200 mouse models have been created or identified in which there is a fertility phenotype (reviewed in refs. 64 and 69). Although this approach has been used on an individual gene basis by specific laboratories, government funding is limited for the production of a knockout mouse of a gene that encodes a protein with no known functional domains. Thus, hundreds of excellent potential contraceptive targets lie dormant because bioinformatics cannot categorize them. Currently, the only way to approach this is to produce antibodies to the novel protein, thereby gaining the wealth of information that is needed to identify reproductive tissue-enriched contraceptive targets that can be further validated using gene-deletion approaches.

Proteomics and systems biology. Detailed proteomic analysis of human, rat, and mouse spermatozoa have now been completed and provide a rational basis for selecting targets for contraceptive development (65). Bioinformatic analyses of these data suggest that approximately $2 \%$ of the sperm proteome is amenable for drug-target validation, with several leading candidates currently in the pipeline for further development, such as the odorant receptors (ORs) and sperm thioredoxins mentioned below (70). In the case of the human sperm proteome, there are at least six seven-pass transmembrane GPCRs, six tyrosine kinase receptors, a tyrosine phosphatase receptor, glutamate-gated ion channel receptors, transient receptor potential cation channels, and a nongenomic progesterone receptor-transmembrane, all of which are potential contraceptive targets, by virtue of being surface receptors amenable to pharmacological intervention (65). The examples given below are being actively pursued from a contraceptive point of view. Of the GPCRs present in human spermatozoa, some of the most interesting from a contraceptive point of view are the ORs, which seem to play key roles in the regulation of sperm movement and chemotactic behavior (ref. 71; see below). Another interesting group of molecules from a contraceptive point of view identified in the sperm proteome are the testes-specific thioredoxins, which are thought to be involved in the redox regulation of sperm function (72) and specifically the control of sperm capacitation and motility.

Challenges to using proteomic information. Although proteomics might provide us with a valuable platform for identifying potential targets for contraceptive development, a clear bottleneck exists in the validation of these leads. Traditionally, the production of knockout mice was used to determine whether or not a particular gene product is essential for fertility. However, this approach has proven unexpectedly challenging. Key proteins found within human spermatozoa that might provide contraceptive targets, including some GPCRs (for example, the ORs; ref. 71), do not possess orthologous proteins present in the mouse genome, making it virtually impossible to move forward with any confidence. The reverse is also apparently true. Further, although putative candidates can be found in the mouse proteome, paralogous proteins (more than one orthologous protein) can be present within the human sperm proteome, creating redundancies that make valida- tion of a particular target extremely difficult. One approach to circumvent this problem is to target a family of proteins, creating a compound directed toward two or more similar proteins known to be present in spermatozoa. However, the validation of this approach still requires the production of knockout mice; only in this case, multiple genes have to be disrupted to provide meaningful evaluation of a given contraceptive approach.

It is clear that careful target identification is a critical component of the contraceptive discovery process. In the context of male fertility control, it has been argued that the posttesticular maturation of spermatozoa in the epididymis and female reproductive tract might provide a better source of contraceptive targets than spermatogenesis in terms of the safety, reversibility, and speed-of-onset of the contraceptive effect (73). The posttesticular remodeling of spermatozoa exclusively involves posttranslational modification of existing proteins as a result of such key processes as phosphorylation, proteolysis, and glycosylation. New technologies in comparative proteomics should be extremely valuable in characterizing these posttranslational modifications and identifying specific targets for further development as contraceptive agents. For example, by focusing on changes in the phospho-proteome it should be possible to highlight kinase- and phosphatase-dependent changes, which should be druggable. In a recent analysis of this type on rat spermatozoa, 9 proteins were found to become phosphorylated during capacitation (R.J. Aitken and M.A. Baker, unpublished observations). The ultimate purpose of such analyses is to generate a short list of sperm-specific, functionally important, druggable targets that can then be taken forward for validation.

\section{New leads for contraceptives}

The foregoing discussion has delineated the power of genomic and proteomic studies to identify thousands of reproductive tissue targets for future contraceptives. Functional contraceptive-relevant data for many of these targets is currently lacking (i.e., gene knockouts or knockdowns have not confirmed an important role for many of these proteins). The information in Table 4 includes a selection of the most interesting targets that are presently subject to intense exploration.

Gametogenesis. Although much is known about the key regulatory molecules involved in both oogenesis and spermatogenesis (69), only a few present themselves as suitable targets for contraception (Table 4) for many reasons (e.g., targeting of some proteins expressed outside the reproductive axis may cause unwanted side effects or others may not be feasible druggable targets). During the process of spermatogonial cell differentiation, male germ cells develop a unique structure called the intercellular bridge $(74,75)$. These intercellular bridges interconnect and link all subsequent male germ cells during mitotic and meiotic divisions. Thus, by the time haploid germ cells are formed, there is a clonally derived syncytium of up to approximately 1,000 germ cells that are interconnected by intercellular bridges. Although proteins involved in the formation of intercellular bridges in the fruit fly have been identified, essential proteins involved in the formation of the mammalian intercellular bridge have not been identified until recently $(74,75)$. Testis-expressed gene 14 (TEX14) was shown to localize specifically to the intercellular bridge throughout spermatogenesis (74) and convert some midbody matrix proteins (i.e., the centralspindlin complex) into stable intercellular bridge components (75). Absence of TEX14 in mice not only disrupts 


\section{Table 4}

Targets for potential contraceptives based on an infertility phenotype induced by gene knockout or antibody or small molecule inhibition

\begin{tabular}{lccc}
\hline & Protein family & & Role \\
Target & Kinase-like domain & Reference \\
TEX14 & Occludin & Component of germ-cell intercellular bridge & 74 \\
Occludin & Steroid-hormone receptor superfamily; retinol-binding & Calcium-dependent cell adhesion molecule in tight junctions & 78,81 \\
RAR $\alpha$ & Glycolytic enzyme & Spermatid maturation & 85 \\
GAPDHS & S subunit calcium channel & Sperm motility & 101 \\
CatSper & Kunitz-type trypsin inhibitor; defensins & Hyperactivated motility & 103 \\
Eppin & Cytokine receptor & Hydrolysis of semenogelin & 48,121 \\
LIFR & Cytokine receptor & Blastocyst implantation & 141 \\
IL-11 receptor & Cytokine receptor & Decidualization & 153 \\
Leptin receptor & Serine protease & Blastocyst implantation & 158 \\
PC6 & & Blastocyst implantation & 167 \\
\hline
\end{tabular}

the intercellular bridge but also causes sterility (74). Since TEX14 and the intercellular bridge are critical for fertility in males, protein components of the intercellular bridge, including TEX14, are potential contraceptive targets.

Recent studies have shown that the chemical Adjudin targets protein complexes (e.g., integrin/laminin and cadherin/catenin) at the apical ectoplasmic specialization, which is restricted to the interface between Sertoli cells and elongating spermatids (step 8 spermatids and beyond) in the rat testis. This induces premature exfoliation of sperm from the seminiferous epithelium by causing anchoring junction disruption between Sertoli cells and spermatids $(76,77)$. This results in a lack of mature spermatozoa in ejaculates, making them unable to fertilize oocytes (76). The effects of Adjudin on male fertility were reversible (76). Due to low oral bioavailability, large doses of Adjudin were required to produce this contraceptive effect, but they also caused liver toxicity, indicating a narrow therapeutic margin (76). FSH receptors are solely present on Sertoli cells in mammals, and so this problem of lack of bioavailability was overcome by using a recombinant, minimally hormonally active mutant FSH molecule to target Adjudin to Sertoli cells. Conjugation of Adjudin and the FSH mutant produced a molecule that, when administered i.p., caused infertility at a dose of Adjudin 100,000 times lower than had been needed orally for the unconjugated Adjudin (77).

Tight junctions create highly selective diffusion barriers that prevent the free passage of molecules and ions. Occludin, a fourpass integral plasma-membrane protein is a functional component of these barriers in rodents $(78,79)$. Combination of the same FSH mutant used to target Adjudin to Sertoli cells with a 22 -amino acid peptide of occludin that is known to disrupt the blood-testis barrier in vivo (80) produced a molecule that bound to the FSH receptors on the Sertoli cells with negligible hormonal activity (81). Injection of this conjugate i.p. in rats caused reversible disruption of the blood-testis barrier and partial germ cell loss from the testis without compromising tight junctions in epithelia of other organs (81). This novel targeting vector provides a specific way of delivering contraceptive molecules to the testis. However, at this point in development, the need to administer the conjugate i.p. makes it impractical for regular contraception. Furthermore, the costs of synthesizing the recombinant FSH mutant make it prohibitively expensive for male contraception. Alternate expression and delivery systems need to be investigated. If these problems can be overcome, occludin could prove to be a viable contraceptive target (Table 4).
The need for dietary retinol (vitamin A) for normal spermatogenesis is well recognized (82-84). Mice lacking retinoic acid receptor- $\alpha($ RAR $\alpha)$, a critical protein for transducing retinoid-mediated signaling, are infertile due to multiple specific defects in spermatogenesis (85). This includes a failure of spermatids to align and be released into the lumen, presumably reflecting aberrant orientation to the Sertoli cells $(85,86)$. BMS- 189453 is a synthetic retinoid that acts as a panantagonist of all three RARs (RAR $\alpha, \operatorname{RAR} \beta$, and RAR $\gamma$ ). Rats and rabbits treated orally with low doses of BMS189453 for only one week exhibited profound testicular toxicity within one month after cessation of treatment and minimal systemic toxicity (87). In contrast to the reversibility observed upon restoration of vitamin A to the diet, the effects of the pan-RAR antagonist were reported to be irreversible (87). However, recent experiments with lower doses of this antagonist have resulted in male infertility that was reversible (D. J. Wolgemuth, personal communication). These results suggest that it might be possible to identify other related small molecules specific for RARs that would interfere with spermatogenesis and yet be reversible.

Gamete transport. Factors influencing sperm transport through the female reproductive tract are regulated to ensure the best chance for motile, healthy spermatozoa to fertilize the oocyte (88). After maturation in the epididymis, many millions of sperm are ejaculated, but only a few thousand reach the site of fertilization in the fallopian tube. The cervix and the uterine lumen pose barriers that must be overcome (89). Sperm transport through the cervix is affected by the state of the cervical mucus. Midcycle mucus under the influence of estrogen is thin and watery and composed of macromolecular fibrils arranged to form micelles large enough to permit sperm passage. In contrast, under progesterone dominance, the mucus is thicker, contains less water, and does not form micelles, thus making it less suitable for sperm passage (90). Creation of such hostile mucus is thought to be the major mechanism of action of progesterone-only contraceptive pills. Endocervical expression of a gel-forming mucin, MUC5B, and of a major membrane-spanning mucin, MUC4, seems to produce mucus, permitting sperm passage through the cervix (91). Increasing progesterone blood levels diminish such expression (91). An agent that could reliably achieve such hostile mucus through a local, nonhormonal, mechanism would be an interesting contraceptive target, but further studies to elucidate the mechanism controlling hormonal regulation of cervical mucus are still needed (91).

It has been known for a long time that men treated with thioridazine, an antipsychotic drug, or phenoxybenzamine, an anti- 
hypertensive agent, become infertile due to failure of ejaculation, even though orgasm is normal $(92,93)$. It was suggested that this contraceptive effect of phenoxybenzamine was due to a selective blockade of $\alpha$-adrenoreceptors in longitudinal but not in circular muscular contractions of the vas deferens (94), a concept that is supported by in vitro observations (95). Work is underway to identify suitable small molecules that could act specifically on the longitudinal muscles of the male reproductive tract. Such an agent would have great attractiveness as a male contraceptive since it could be taken orally only hours before need and its effects could be completely dissipated within 24 hours.

The glycolytic pathway is modified extensively in mammalian spermatozoa and includes multiple isozymes that are not expressed in somatic tissues. GAPDHS (known as GAPDH-2 in humans), phosphoglycerate kinase 2, and two aldolase isozymes (ALDOART1 and ALDOART2) are encoded by genes expressed only during spermatogenesis (96-99). Other novel isozymes in sperm, such as hexokinase $1-S$, are generated by alternative splicing events that occur only in the male germ line (100). GAPDHS and several other glycolytic enzymes are tightly bound to the fibrous sheath, a cytoskeletal structure in the principal piece of sperm flagella (98). Consistent with these findings, glycolysis in mature spermatozoa is only observed in the principal piece. Generation of mice lacking GAPDHS demonstrated that this protein is essential for sperm motility and male fertility (101). In the rat, the GAPDHS transcript is found only in the testis and first appears about day 29 after birth (102). Transcripts were only found in round and condensing spermatids, demonstrating haploid expression of the GAPDHS gene (102). These findings suggest that inhibition of human sperm GAPDHS, either in the male reproductive tract or the female reproductive tract (e.g., through a small molecule applied vaginally), might inhibit sperm motility and prevent fertilization (Table 4).

Motility is required for normal fertility. When sperm enter the alkaline environment in the upper portion of the female reproductive tract, they exhibit a specialized pattern of motility termed byperactivation by which the flagellar wave generates high levels of forward thrust (88). This hyperactivated motility requires $\mathrm{Ca}^{2+}$ entry (103). Among the $\mathrm{Ca}^{2+}$ channels that have been identified in sperm are the CatSpers. Four sperm-expressed CatSper proteins have been found to date $(104,105)$. It seems that $\mathrm{Ca}^{2+}$ influx into the principal piece of the sperm via the CatSper (CatSper1-CatSper4) channels initiates hyperactivated motility and a tail-to-head propagation, leading to an increase in NADH (106). Absence of any one of the four CatSpers in mouse sperm results in an identical phenotype, i.e., no effect on initial sperm motility, but abolition of hyperactivated motility, resulting in infertility $(103,105,107-109)$. Consistent with these findings and the observation that the localization of each of the CatSper proteins in the principal piece is similar (107-109), the four CatSper proteins seem to be subunits of the same cation channel. In addition, infertile men who lack sperm motility exhibit decreased CATSPER gene expression compared with men infertile for other reasons (110). Hence, blockade of the spermatozoa CATSPER cation channel in the male or female tract might be expected to have a contraceptive effect (Table 4).

Although one would expect ORs to be unique to the sensory neurons of the olfactory epithelium, a number are also expressed in mammalian sperm (111). Studies over many decades have suggested that sperm can exhibit chemotaxis in response to spe- cific chemicals and the products of ovulation (112). However, the connection between ORs and chemotaxis was only made more recently (111). Signaling through a specific human testicular OR, hOR17-4, caused both chemokinetic and chemotactic responses by sperm in vitro $(71,111)$. Bourgeonal was identified as an agonist that could stimulate these responses, whereas undecanol functioned as an antagonist of these effects $(71,111)$. Signaling through additional ORs seems to stimulate specific responses in sperm (71). The endogenous ligands in the female reproductive tracts that cause these responses are likely to be reported shortly. These studies indicate that agonists and/or antagonists of one or more OR signaling pathways might be excellent contraceptives that would be effective in the female reproductive tract.

Fertilization. Although considerable progress has been made in identifying egg and sperm components involved in each of the steps that lead to fertilization, several issues remain unresolved or contentious. For example, although numerous candidates have been reported $(113,114)$, the precise nature of the sperm proteins that bind zona pellucida protein 3 (ZP3) on the oocyte is unclear. Similarly, there is a great deal of confusion as to which sperm and egg proteins are actually involved in binding and fusion of gametes (115).

One recent lead is Eppin (48). In the human, sperm rapidly begin to swim into the cervical canal after ejaculation (116). Human semen coagulates as a loose gel that is enzymatically degraded within one hour, enabling the sperm to move more freely along the reproductive tract toward the oocyte (117). The predominant structural components of the vesicular gel are semenogelin I and semenogelin II, which are degraded by the serine protease prostatespecific antigen (PSA) (118). Eppin, which originates from Sertoli and epididymal epithelial cells, binds semenogelin and inhibits the activity of PSA and therefore the hydrolysis of semenogelin (119, 120). The C-terminal portion of Eppin is structurally homologous to the Kunitz-type trypsin inhibitor, and the N-terminal has structural similarity to defensins (121). Human sperm have receptors for Eppin, and antibodies specific for Eppin cause infertility in male monkeys, which is reversed as antibody levels fall (48). It is suggested that Eppin-specific antibodies bound to Eppin on the sperm surface block the binding site for semenogelin (121). Development of small molecules that would block this binding site might be expected to be contraceptive (Table 4).

The high rate of HIV infections acquired through sexual activity warrants the development of novel compounds displaying contraceptive and microbicidal anti-HIV properties. Some of the molecules and mechanisms used by sperm to fertilize the egg are similar, if not identical, to those used by HIV to infect host cells (122). An example of common structures is the lipid membrane surrounding the spermatozoan and the HIV core (122). Disruption of the architecture of the lipid membrane by surface-active compounds exerts both spermicidal and virucidal activity (123). A more specific alteration of lipid rafts by $\beta$-cyclodextrins also has similar effects (124). During fertilization and infection, both sperm and HIV interact with their target cells through chemical charges, hydrophobic forces, and carbohydrate recognition. Anionic polymers such as cellulose sulfate and polystyrene sulfonate inhibit sperm and HIV cell binding and have been shown to have contraceptive effects (Table 3 ). Since some of the molecules involved in the interaction between sperm and oocytes are also used by other pathogens to infect their target tissues, polyanions exert broad antimicrobial activity as well as contraceptive effects. 
During fertilization and infection, sperm and HIV, as well as other microbes, use signal transduction molecules and mechanisms such as adenyl cyclase/cAMP-dependent kinase, calcium, and tyrosine phosphorylation, whose inhibition has been shown to impair sperm function and HIV replication (122). These commonalities at the level of sperm and HIV structure, cell binding and fusion processes, and signaling pathways therefore provide the biological framework to develop bifunctional inhibitors with both antimicrobial and contraceptive properties (122).

Implantation: steroidal approaches. The search for agents that work postovulation up to and including blastocyst attachment to the endometrium has been vigorously pursued for over 50 years. However, the animal models used in most studies were rats or mice, which eventually proved to be unsuitable, since they require ovarian estrogen to initiate the process of implantation, whereas primates do not $(125,126)$. Hence, selective estrogen receptor modulators (SERMs) will not be contraceptives in women. However, the discovery of progesterone receptor modulators (PRMs), which are steroids with antiprogestational activity (as opposed to progestational activity), has provided a different approach to inhibition of ovulation and implantation than that utilized by current progestin-based OCs. For example, the PRM mifepristone can terminate pregnancy in women when taken orally after a missed menses, especially when combined with a prostaglandin, which progestins cannot (127). In addition, administration of $200 \mathrm{mg}$ mifepristone alone on day LH plus 2 prevented pregnancy in all but 1 of 157 cycles in fertile women, resulting in a Pearl index of 7.6 (128). Since, in this case, the drug was administered after ovulation, it must have exerted its effect on the fallopian tube or endometrium (128). In contrast, oral daily doses of 2 or $4 \mathrm{mg}$ of mifepristone inhibit ovulation and menstruation in most cycles in women, while maintaining follicle development and estradiol levels (129). No pregnancies were observed in 59 women over 200 months of daily exposure (129). This regimen has not become available, since the toxicology done on mifepristone is only adequate to support infrequent use for abortion or emergency contraception. VA2914, another PRM, has also been studied for its potential as a daily OC pill and been found to inhibit ovulation and induce amenorrhea in over $80 \%$ of women (130).

Implantation: nonsteroidal approaches. The failure of random screening to produce viable leads for anti-implantation agents led to the need to select targets for which proof of principle could be demonstrated. Microarrays of endometrial genes have permitted assessment of which genes are upregulated and which downregulated during the window of endometrial receptivity for implantation (131-137). Although there are similarities in gene profiles generated by different laboratories, there are also surprising discrepancies, and two recent papers have concluded that the key molecules and mechanisms regulating endometrial receptivity have yet to be elucidated $(138,139)$. In reality, many of the genes of current interest were being worked upon before the advent of microarrays. Some possible endometrial targets are described below. All of them raise questions as to specificity to the reproductive tract, but results from animal experiments (knockout mice or inhibition of action by antibodies or peptides) have not, so far, shown reason for concern. However, this is an area that requires vigilant monitoring, and appropriate toxicology tests will need to be conducted as research develops.

Leukemia inhibitory factor (Lif) mRNA appears in the endometrial glands of the mouse uterus on day 4 of pregnancy and pseu- dopregnancy but is absent in nonpregnant mice (140). In mice lacking LIF, although males were fertile, females were infertile due to failure of blastocysts to implant in the uterus (141). LIF protein is upregulated by estradiol in the mouse uterus but by progesterone in rabbits (142). In women, the situation is not so clear-cut. In nonconception cycles, both mRNA and protein are low or absent during the follicular (proliferative) phase but rise in the glands and luminal epithelium during the luteal (secretory) phase $(143,144)$. LIF signals through a high-affinity receptor comprised of LIF receptor (LIFR) and GP130, which mediates signal transduction through the JAK/STAT pathway $(145,146)$. GP130 is also a component of a number of other cytokine receptors, including those for IL-6, IL-11, ciliary neurotrophic factor, and oncostatin $\mathrm{M}$ (147). In contrast to Lif-deficient mice, germline deletion of the gene encoding LIFR is lethal (148). Instillation of either polyclonal or monoclonal antibodies against recombinant human LIF into the uterine cavity markedly reduces the pregnancy rate in monkeys $(149,150)$. Given these facts, small peptides that bind to the receptor without signal activation have been developed by mutation of recombinant human LIF, resulting in an inhibitor of LIFR that binds human LIFR more than 1,000 times more strongly than the native molecule (151). In vitro, this antagonist abrogated cell signaling to LIF (151). This antagonist totally blocked implantation in mice despite its short half-life, when given multiple times from day 2.5 to day 4 of pregnancy (152). To extend the half-life, the antagonist was conjugated to polyethylene glycol (PEGylated), which substantially raised serum levels of the antagonist and inhibited pregnancy when given by only 3 i.p. injections between day 2.5 and day 3.5 of pregnancy (152). The antagonist had no lethal effects on embryos (152).

Mice lacking the $\alpha$-subunit of the IL-11 receptor also show an antifertility phenotype due to disturbance of the decidualization process (153). Both the IL-11 receptor mRNA and protein are highly expressed in human and monkey endometrium around the time of decidualization $(154,155)$. IL-11 also signals through the JAK/STAT pathway $(156,157)$. Similar technology to that used to generate LIFR inhibitors has been used to make inhibitors of IL-11 receptor, but these have yet to be tested in vivo.

Leptin is a peptide that regulates food intake and energy balance, but in mice with the gene encoding this protein knocked out, there is a phenotype of infertility with reduced formation of blastocysts (158). Leptin and its receptor are expressed in human endometrium during the luteal phase, and endometrial leptin secretion is regulated by the developing blastocyst (159). In cultured endometrial epithelial cells, leptin increases the levels of LIFR, LIF, IL-1, IL-1 receptor, IL-1 receptor antagonist, and phosphorylated STAT3 (160). These effects could be blocked by antibodies against LIFR or an inhibitory leptin peptide. It therefore was concluded that leptin binding to its receptor activates the JAK2/STAT3 signaling pathway, as seen for LIF (160). Leptin also inhibits decidualization of stromal cells in vitro (161). An antagonist of leptin has been made by synthesis of a small peptide comprising helix III residues 70-95 of human leptin (162). This antagonist binds specifically and with high affinity to the leptin receptor and potently inhibits leptin function in endometrial cells in vitro. An antagonist given into the uterine lumen of mice on day 3 of pregnancy substantially reduced the number of uterine horns with implantations; a scrambled peptide had no effect (163). The half-life of the antagonist was very short ( 1-2 hours). 
To reduce metabolism, the antagonist was PEGylated, and the half-life increased to 19-68 hours, depending on the route of administration. The antagonist, with or without PEGylation, was absorbed from a vaginal gel formulation and localized to the leptin receptors in the mouse uterus (164). Vaginal treatment with the PEGylated antagonist on days 1-6 postcoitum in mice completely prevented implantation (165). Pharmacokinetic studies with radiolabeled antagonist revealed localization mainly in the ovaries, uterus, and mammary glands, and no significant amounts in the central nervous system (164). In addition, there was no effect on energy metabolism (165). These results indicate that reproductive organs can be affected by the inhibitory peptide without any traverse of the blood-brain barrier or interference with energy metabolism.

A project supported by the WHO and the Rockefeller Foundation Initiative on Implantation identified an interesting molecule, proprotein convertase 6 (PC6), which is expressed in both mouse and human endometrium (166). PC6 is a member of a family of serine proteases responsible for posttranslational processing and activation of many regulatory proteins. Temporal and spatial mRNA and protein expression were congruent with the window of uterine receptivity (166). Inhibition of implantation was achieved by blocking PC6 protein production in the mouse uterus by use of intraluminally administered morpholino antisense oligonucleotides (167). To determine the specificity of PC6 for implantation, endometrial expression of all PCs during the menstrual cycle was studied. Only PC6 was markedly upregulated during decidualization, while the other PCs were constitutively expressed (168). Short polybasic peptide sequences have been shown to be potent inhibitors of PC6 (169), and one of these is being used in antifertility tests in mice.

\section{Research and development key challenges}

During the development of any new contraceptive drug, there are certain key questions to be considered. The most important is target validation, which can be accomplished by using knockout mice, antibodies, and known inhibitors. The target, if validated in the mouse, must have a human homolog. Specificity of expression of the target to reproductive organs is important, but it might not need to be absolute. However, other family members should not be able to substitute for the target molecule. Preferably, the target should be druggable; ion channels, enzymes, and receptors are good targets for small molecule inhibitors, but inhibitory small peptides should also be considered. Some of the antagonists under development are peptides, and this makes them unsuitable for oral administration. Other routes of administration, such as nasal sprays, transdermal delivery or vaginal application of gel formulations, and device delivery seem to be most practical. It is known that small peptides, e.g., magainin II amide (23 amino acids), delivered by vaginal tampon can be taken up in sufficient amount to prevent implantation in rhesus monkeys (170). For proof-of-principle studies in animal models, vaginal gels seem the simplest, even if less suitable for the clinic because of lower patient compliance with gels compared with pills, injectables, and devices. Assays for the specific class of molecules must be available or able to be developed. Focused libraries of compounds for the molecule class are useful. If industry is to be a collaborator, then patent protection and freedom to operate without infringing existing patents is critical. For the public sector, this might not be so important.
In the past, developers of contraceptives have tended to be overly optimistic about the development time $(10,11)$, which has led to donor fatigue, since in many instances donors have a much shorter time frame for results than developers. The translational process from target identification and validation to the clinic is long: if all goes well, at least 5 years, but at a small cost compared with that for clinical trials. Many leads fail at this stage and so a pipeline of potential replacements is essential for sound project management. Once the selected lead compound is in the clinic, from phase I to III can easily take $10-15$ years and many millions of dollars, and so if the lead should fail, it is better that it be as early as possible in the translational process. One way to speed progress is by use of surrogate endpoints for pregnancy. For example, spermicidal compounds can be assessed by use of postcoital tests, which although difficult to do and not $100 \%$ certain, can be done in much less time and at lesser cost than a phase II efficacy trial. In contrast, an agent that prevents fertilization by inhibition of sperm enzymes will not give a positive result in a postcoital test. Ultrasound is useful for detection of follicle rupture and prevention of ovulation. Still, in many instances there is no substitute for an inhibition of pregnancy trial. How important it is to have shown a positive result in a nonhuman primate species is debatable. The difficulty here is that these studies are also complicated and expensive (large enough group sizes for statistical power) and there is, at best, a $65 \%$ conception rate in sham-treated controls. There is a lack of centers with expertise in such studies. So, all things being equal, a positive result would be helpful but should not be the gatekeeper to moving forward.

A case has been made for the need for public-private partnerships to expedite the research and development process for new contraceptives $(2,3)$, but in the past 10 years, the few big pharmaceutical companies active in contraceptive research have almost all closed their research laboratories and plan instead to insource new drugs when they have been fully developed by others. Given the reduction in funding for contraceptive research and development, it is important to re-energize the enthusiasm of potential funding sources, such as philanthropic foundations, as a major source for such funding. Whether it will be possible to maintain the existing low level of funding is uncertain. Inadequate funding means significant delays in the translational process. A concluding question is that if funding were not constrained, starting from where we are today, could we develop one new male and one new female nonhormonal contraceptive method by the year 2027? Despite the perils of prognostication, we are cautiously optimistic that this is possible.

\section{Acknowledgments}

Thanks are due to the following individuals who reviewed different sections to ensure that the latest and most correct information has been incorporated into this review: Deborah O'Brien, Yan Cheng, Douglas Colvard, Evdokia Dimitriadis, Ruben Gonzalez, Guying Nie, Michael O'Rand, Jeffrey Spieler, and Debra Wolgemuth.

Address correspondence to: Michael J.K. Harper, CONRAD, Eastern Virginia Medical School, 1611 North Kent St., Suite 806, Arlington, Virginia 22209, USA. Phone: (703) 524-4744; Fax: (703) 524-4770; E-mail: mharper@conrad.org.

All authors contributed equally to this work. 
1. Global Health Council. 2008. Women's health. http://www.globalhealth.org/view_top. php3?id=225.

2. Harrison, P.F., and Rosenfeld, A. 1996. Contraceptive research and development: looking to the future. Institute of Medicine report. National Academy Press. Washington, DC, USA. 519 pp.

3. Nass, S.J., and Strauss, J.F., 3rd. 2004. New frontiers in contraceptive research: a blueprint for action. Institute of Medicine report. National Academy Press. Washington, DC, USA. 232 pp.

4. Pincus, G., and Chang, M.C. 1953. The effects of progesterone and related compounds on ovulation and early development in the rabbit. Acta Physiol. Lat. Am. 3:177-183.

5. Garcia, C.R., Rock, J., and Pincus, G. 1956. Effects of certain 19-norsteroids on the normal human menstrual cycle. Science. 124:891-893.

6. Rock, J., Garcia, C.R., and Pincus, G. 1957. Synthetic progestins in the normal human menstrual cycle. Rec. Progr. Horm. Res. 13:323-339.

7. Sivin, I., et al. 1991. Prolonged intrauterine contraception: a seven-year randomized study of the levonorgestrel $20 \mathrm{mcg} /$ day (LNg 20) and the Copper T380 Ag IUDS. Contraception. 44:473-480.

8. Cox, M., and Blacksell, S.E. 2000. Clinical performance of the Nova-T380 IUD in routine use by the UK Family Planning and Reproductive Health Research Network:12-month report. Br. J. Fam. Plann. 26:148-151.

9. Chrisman, C., Ribeiro, P., and Dalton, V.K. 2007. The levonorgestrel-releasing intrauterine system: an updated review of the contraceptive and noncontraceptive uses. Clin. Obstet. Gynecol. 50:886-897.

10. Harper, M.J.K. 1983. Birth control technologies: prospects by the year 2000. University of Texas Press. Austin, Texas, USA. $271 \mathrm{pP}$

11. Harper, M.J.K. 2005. In search of a second contraceptive revolution. Sexuality, Reproduction and Menopause. 3:59-67.

12. Strauss, J.F., 3rd, and Kafrissen, M. 2004. Waiting for the second coming. Nature. 432:43-45.

13. All Party Parliamentary Group on Population, Development and Reproductive Health. 2007. Return of the population growth factor: its impact on the millennium development goals. http:// www.appg-popdevrh.org.uk.

14. Djerassi, C. 2005. No political will to seek innovative contraception. Focus on other birth control issues, which may make birth-control superfluous. Nature. 433:683.

15. Collumbien, M., Gerresu, M., and Cleland, J. 2004 Non-use and use of ineffective methods of contraception. In Quantification of health risks: global and regional burden of disease attributable to selected major risk factors. M. Ezzati, A. Lopez, A. Rodgers, and C. Murray, editors. World Health Organization. Geneva, Switzerland. 1255-1320.

16. Sedgh, G., Hussain, R.R., Bankole, A., and Singh, S. 2007. Women with an unmet need for contraception in developing countries and their reasons for not using a method. Occasional report no. 37. Guttmacher Institute. New York, New York, USA. http://gutmacher.org/pubs/2007/07/09/or37.pdf.

17. Frost, J.J., Singh, S., and Finer, L.B. 2007. Factors associated with contraceptive use and nonuse, United States, 2004. Perspect. Sex. Reprod. Health. 39:90-99.

18. Feldblum, P.J., et al. 2007. Pregnancy among sex workers participating in a condom intervention trial highlights the need for dual protection. Contraception. 76:105-110.

19. Potts, M., and Fotso, J.-C. 2007. Population growth and the Millenium Development Goals. Lancet. 369:354-355.

20. Hatcher, R.A., et al. 2004. Contraceptive technology. 18 th edition. Ardent Media Inc. New York, New York, USA. 871 pp.
21. Mishell, D.R., Jr. 2004. State of the art in hormonal contraception. Am. J. Obstet. Gynecol. 190(Suppl. 4):S1-S4.

22. Novikova, N., Weisberg, E., Stanczyk, F.Z., Croxatto, H.B., and Fraser, I.S. 2007. Effectiveness of levonorgestrel emergency contraception given before or after ovulation - a pilot study. Contraception. 75:112-118.

23. Creinin, M.D., et al. 2006. Progesterone receptor modulator for emergency contraception: a randomized controlled trial. Obstet. Gynecol. 108:1089-1097.

24. Massai, M.R., et al. 2007. Does meloxicam increase the incidence of anovulation induced by a single administration of levonorgestrel in emergency contraception? A pilot study. Hum. Reprod. 22:434-439.

25. Bata, M.S., Al-Ramahi, M., Salhab, A.S., Gharaibeh, M.N., and Schwartz, J. 2006. Delay of ovulation by meloxicam in healthy cycling volunteers: A placebo-controlled, double-blind, crossover study. J. Clin. Pharmacol. 46:925-932.

26. Cole, J.A., Norman, H., Doherty, M., and Walker, A.M. 2007. Venous thromboembolism, myocardial infarction, and stroke among transdermal contraceptive system users. Obstet. Gynecol. 109:339-346.

27. Jick, S.S., and Jick, H. 2007. The contraceptive patch in relation to ischemic stroke and acute myocardial infarction. Pharmacotherapy. 27:218-220.

28. Jick, S., Kaye, J.A., Li, L., and Jick, H. 2007. Further results on the risk of nonfatal venous thromboembolism in users of the contraceptive transdermal patch compared to users of oral contraceptives containing norgestimate and 35 microg of ethinyl estradiol. Contraception. 76:4-7.

29. Shaarawy, M., El-Mallah, S.Y., Seoudi, S., Hassan, M., and Mohsen, I.A. 2006. Effects of the long-term use of depot medroxyprogesterone acetate as hormonal contraceptive on bone mineral density and biochemical markers of bone remodeling. Contraception. 74:297-302.

30. Clark, M.K., Sowers, M., Levy, B., and Nichols, S. 2006. Bone mineral density loss and recovery during 48 months in first-time users of depot medroxyprogesterone acetate. Fertil. Steril. 86:1466-1474.

31. Beksinska, M.E., Kleinschmidt, I., Smit, J.A., and Farley, T.M. 2007. Bone mineral density in adolescents using norethisterone enanthate, depotmedroxyprogesterone acetate or combined oral contraceptives for contraception. Contraception. 75:438-443.

32. [No authors listed]. 2007. Proceedings of the Fifth International Symposium on Intrauterine Devices and Systems for Women's Health. October 27-28, 2006. New York, New York, USA. Contraception. 75(Suppl. 6):S1-S166.

33. Sheckter, C.B., Matsumoto, A.M., and Bremner, W.J. 1989. Testosterone administration inhibits gonadotropin secretion by an effect directly on the human pituitary. J. Clin. Endocrinol. Metab. 68:397-401.

34. McLachlan, R.I., et al. 2002. Hormonal regulation of spermatogenesis in primates and man: Insights for development of the male hormonal contraceptive. J. Androl. 23:149-162.

35. World Health Organization Task Force on Methods for the Regulation of Male Fertility. 1990. Contraceptive efficacy of testosterone-induced azoospermia in normal men. Lancet. 336:955-959.

36. McLachlan, R.I., et al. 2004. Relationship between serum gonadotropins and spermatogenic suppression in men undergoing steroidal contraceptive treatment. J. Clin. Endocrinol. Metab. 89:142-149.

37. Turner, L., et al. 2003. Contraceptive efficacy of a depot progestin and androgen combination in men. J. Clin. Endocrinol. Metab. 88:4659-4667.

38. Grimes, D.A., et al. 2007. Steroid hormones for contraception in men. Cochrane Database of Systematic Reviews. 2:CD004316

39. World Health Organization Task Force on Methods for the Regulation of Male Fertility. 1996.
Contraceptive efficacy of testosterone-induced azoospermia and oligospermia in normal men. Fertil. Steril. 65:821-829.

40. Meriggiola, M.C., et al. 2005. Norethisterone enanthate plus testosterone undecanoate for male contraception: effects of various injection intervals on spermatogenesis, reproductive hormones, testis, and prostate. J. Clin. Endocrinol. Metab. 90:2005-2014.

41. Abbott, J. 2007. Transcervical sterilization. Curr. Opin. Obstet. Gynecol. 19:325-330.

42. Lohiya, N.K., Manivannan, B., Mishra, P.K., and Pathak, N. 2001. Vas deferens, a site of male contraception: an overview. Asian J. Androl. 3:87-95

43. Zaneveld, L.J.D., De Castro, M.P., Faria, G., et al. 1998. The soft hollow plug ("SHUG"): a potentially reversible vas deferens blocking device. In Male contraception: present and future. P.D. Griffin and M. Rajalakshmi, editors. New Age International. New Delhi, India. 293.

44. Guha, S.K., et al. 1997. Phase II clinical trial of a vas deferens injectable contraceptive for the male. Contraception. 56:245-250.

45. Lohiya, N.K., Manivannan, B., Mishra, P.K., Pathak, N., and Balasubramanian, S.P.A. 1998. Intravasal contraception with styrene maleic anhydride and its noninvasive reversal in langur monkeys (Presbytis entellus entellus). Contraception. 58:119-128.

46. Delves, P.J., and Roitt, I.M. 2005. Vaccines for the control of reproduction - status in mammals, and aspects of comparative interest. Dev. Biol. (Basel) 121:265-273.

47. Cui, C., Stevens, V.C., and Schwendeman, S.P. 2007. Injectable polymer microspheres enhance immunogenicity of a contraceptive peptide vaccine. Vaccine. 25:500-509.

48. O'Rand, M.G., et al. 2004. Reversible immunocontraception in male monkeys immunized with Eppin. Science. 306:1189-1190.

49. Moench, T.R., Chipata, T., and Padian, N.S. 2001. Preventing disease by protecting the cervix: the unexplored promise of internal vaginal barrier devices. AIDS. 15:1595-1602.

50. Padian, N.S., et al. 2007. Diaphragm and lubricant gel for prevention of HIV acquisition in southern African women: a randomized controlled trial. Lancet. 370:251-261.

51. Hoffman, S., Mantell, J., Exner, T., and Stein, Z. 2004. The future of the female condom. Int. Fam. Plan. Perspect. 30:139-145.

52. The Female Health Company: developer and manufacturer of FC and FC2 female condom. http:// www.femalehealth.com/.

53. Belinska, M., Smit, J., Mabude, Z., Vijayakumar, G., and Ioannis, C. 2006. Performance of the "Reality" polyurethane female condom and a synthetic latex prototype: a randomized crossover trial among South African women. Contraception. 73:386-393.

54. Smit, J., Belinska, M., Vijayakumar, G., and Mabude, Z. 2006. Short-term acceptability of the Reality polyurethane female condom and a synthetic latex prototype: a randomized cross-over trial among South African women. Contraception. 73:394-398.

55. Joanis, C., Lopez, L.M., Gomez, K., Ramm, K., and Rottjakob, D. 2007. Efficacy of a dish detergent in reducing populations of STI organisms in inoculated female condoms. Int. J. STD. AIDS. 18:198-201.

56. Smita, J., et al. 2005. Comparative acceptability study of the Reality female condom and the version 4 of modified Reddy female condom in India. Contraception. 72:366-371.

57. Van Damme, L., et al. 2002. Effectiveness of COL1492, a nonoxynol-9 vaginal gel, on HIV-1 transmission in female sex workers: a randomized controlled trial. Lancet. 360:971-977.

58. Fichorova, R.N., Tucker, L.D., and Anderson, D.J. 2001. The molecular basis of nonoxynol-9-induced 
vaginal inflammation and its possible relevance to human immunodeficiency virus type 1 transmission. J. Infect. Dis. 184:418-428.

59. Fichorova, R.N., et al. 2004. Interleukin (IL)-1, IL-6, and IL-8 predict mucosal toxicity of vaginal microbicidal contraceptives. Biol. Reprod. 71:761-769.

60. Alliance for Microbicide Development. 2007. Microbicide candidates in ongoing clinical trials: summary as of December 2007. http://www.microbicide.org/microbicideinfo/reference/Microbicide. Ongoing.Clinical.Trials.Summary07Dec07.pdf.

61. Anderson, R.A., et al. 2002. Preclinical evaluation of sodium cellulose sulfate (Ushercell) as a contraceptive antimicrobial agent. J. Androl. 23:426-438.

62. Mauck, C.K., et al. 2006. Noncomparative contraceptive effectiveness trial of Cellulose Sulfate gel. American College of Obstetricians and Gynecologists' 54th Annual Clinical Meeting (ACM). May 6-10. Washington, DC, USA. 14S.

63. Van Damme, L., et al. 2007. Phase III trial of $6 \%$ cellulose sulfate (CS) gel for the prevention of HIV transmission. 4th IAS Conference on HIV Pathologies, Treatment and Prevention. July 22-25. Sydney, New South Wales, Australia. International AIDS Society. http://www.ias2007.org/pag/Abstracts. aspx?AID $=5344$

64. Matzuk, M.M., and Lamb, D.J. 2002. Genetic dissection of mammalian fertility pathways. Nat. Med. 8:S41-S49.

65. Baker, M.A., et al. 2007. Identification of gene products present in Triton X-100 soluble and insoluble fractions of human spermatozoa lysates using LCMS/MS analysis. Proteomics - Clinical Applications. 1:524-532.

66. Schultz, N., Hamra, F.K., and Garbers, D.L. 2003. A multitude of genes expressed solely in meiotic or postmeiotic spermatogenic cells offers a myriad of contraceptive targets. Proc. Natl. Acad. Sci. U. S. A. 100:12201-12206.

67. Andreu-Vieyra, C., Lin, Y.N., and Matzuk, M.M. 2006. Mining the oocyte transcriptome. Trends Endocrinol. Metab. 17:130-143.

68. Lin, Y.N., and Matzuk, M.M. 2005. High-throughput discovery of germ-cell-specific genes. Semin. Reprod. Med. 23:201-212.

69. Roy, A., and Matzuk, M.M. 2006. Deconstructing mammalian reproduction: using knockouts to define fertility pathways. Reproduction. 131:207-219.

70. Overington, J.P., Al-Lazikani, B., and Hopkins, A.L. 2006. How many drug targets are there? Nat. Rev. Drug Discov. 5:993-996.

71. Spehr, M., Schwane, K., Riffell, J.A., Zimmer, R.K., and Hatt, H. 2006. Odorant receptors and olfactory-like signaling mechanisms in mammalian sperm. Mol. Cell. Endocrinol. 250:128-136.

72. Miranda-Vizuete, A., et al. 2004. The mammalian testis-specific thioredoxin system. Antioxid. Redox Signal. 6:25-40.

73. Cooper, T.G., and Yeung, C.H. 1999. Recent biochemical approaches to post-testicular, epididymal contraception. Hum. Reprod. Update. 5:141-152.

74. Greenbaum, M.P., et al. 2006. TEX14 is essential for intercellular bridges and fertility in male mice. Proc Natl. Acad. Sci. U. S. A. 103:4982-4987.

75. Greenbaum, M.P., Ma, L., and Matzuk, M.M. 2007. Conversion of midbodies into germ cell intercellular bridges. Dev. Biol. 305:389-396.

76. Cheng, C.Y., et al. 2005. AF-2364 [1-(2,4-dichlorobenzyl)-1H-indazole-3-carbohydrazide] is a potential male contraceptive: a review of recent data. Contraception. 72:251-261.

77. Mruk, D.D., Wong, C.-H., Silvestrini, B., and Cheng, C.Y. 2006. A male contraceptive targeting germ cell adhesion. Nat. Med. 12:1323-1328.

78. Furuse, M., et al. 1993. Occludin: a novel integral membrane protein localizing at tight junctions. J. Cell Biol. 123:1777-1788.

79. Ando-Akatsuka, Y., et al. 1996. Interspecies diversity of the occludin sequence: cDNA cloning of human, mouse, dog, and rat-kangaroo homologues. J. Cell Biol. 133:43-47.

80. Chung, N.P.Y., Mruk, D., Mo, M.Y., Lee, W.M., and Cheng, C.Y. 2001. A 22-amino acid synthetic peptide corresponding to the second extracellular loop of rat occludin perturbs the blood-testis barrier and disrupts spermatogenesis reversibly in vivo. Biol. Reprod. 65:1340-1351.

81. Wong, C.-H., Mruk, D.D., Lee, W.M., and Cheng, C.Y. 2007. Targeted and reversible disruption of the blood-testis barrier by an FSH mutant-occludin peptide conjugate. FASEB J. 21:438-448.

82. Wolbach, S.B., and Howe, P.R. 1925. Tissue changes following deprivation of fat-soluble A vitamin. J. Exp. Med. 42:753-777.

83. Howell, J.M., Thompson, J.N., and Pitt, G.A.J. 1963 Histology of the lesions produced in the reproductive tract of animals fed a diet deficient in vitamin $\mathrm{A}$ alcohol but containing vitamin $\mathrm{A}$ acid. I. The male rat. J. Reprod. Fertil. 5:159-167.

84. Chung, S.S.W., and Wolgemuth, D.J. 2004. Role of retinoid signaling in the regulation of spermatogenesis. Cytogenet. Genome Res. 105:189-202.

85. Chung, S.S., Wang, X., and Wolgemuth, D.J. 2005 Male sterility in mice lacking retinoic acid receptor alpha involves specific abnormalities in spermiogenesis. Differentiation. 73:188-198.

86. Chung, S.S., Sung, W., Wang, X., and Wolgemuth, D.J. 2004. Retinoic acid receptor alpha is required for synchronization of spermatogenic cycles and its absence results in progressive breakdown of the spermatogenic process. Dev. Dyn. 230:754-766.

87. Schulze, G.E., et al. 2001. BMS-189453, a novel retinoid receptor antagonist, is a potent testicular toxin. Toxicol. Sci. 59:297-308.

88. Suarez, S.S., and Pacey, A.A. 2006. Sperm transport in the female reproductive tract. Hum. Reprod. Update. 12:23-37.

89. Harper, M.J.K. 1994. Gamete and zygote transport. In The physiology of reproduction. 2 nd edition. E. Knobil et al., editors. Raven Press. New York, New York, USA. $123-185$

90. Elstein, M., Moghissi, K.S., and Borth, R. 1973. Cervical mucus in buman reproduction. Scriptor. Copenhagen, Denmark.173 pp.

91. Gipson, I.K. 2001. Mucins of the human endocervix. Front. Biosci. 6:D1245-D1255.

92. Greenberg, H.R., and Carrillo, C. 1968. Thioridazine-induced inhibition of masturbatory ejaculation in an adolescent. Am. J. Psychiat. 124:991-993.

93. Kedia, K.R., and Persky, L. 1981. Effect of phenoxybenzamine (dibenzyline) on sexual function in man. Urology. 18:620-622.

94. Amobi, N.I., and Smith, I.C. 1995. Differential inhibition in the human vas deferens by phenoxybenzamine: a possible mechanism for its contraceptive action. J. Reprod. Fertil. 103:215-221.

95. Amobi, N., et al. 2003. Contractile actions of imidazoline alpha-adrenoceptor agonists and effects of noncompetitive alpha 1-adrenoceptor antagonists in human vas deferens. Eur. J. Pharmacol. 462:169-177.

96. McCarrey, J.R., and Thomas, K. 1987. Human testisspecific PGK gene lacks introns and possesses charcteristics of a processed gene. Nature. 326:501-505.

97. Welch, J.E., Schatte, E.C., O’Brien, D.A., and Eddy, E.M. 1992. Expression of a glyceraldehyde 3-phosphate dehydrogenase gene specific to mouse spermatogenic cells. Biol. Reprod. 46:869-878.

98. Krisfalusi, M., Miki, K., Magyar, P.L., and O'Brien, D.A. 2006. Multiple glycolytic enzymes are tightly bound to the fibrous sheath of mouse spermatozoa. Biol. Reprod. 75:270-278.

99. Vemuganti, S.A., et al. 2007. Three male germlinespecific Aldolase A isozymes are generated by alternative splicing and retrotransposition. Dev. Biol. 309:18-31.

100.Nakamura, N., Shibata, H., O’Brien, D.A., Mori, C., and Eddy, E.M. 2008. Spermatogenic cell-specific type 1 hexokinase is the predominant hexokinase in sperm. Mol. Reprod. Dev. 75:632-640.

101.Miki, K., et al. 2004. Gyceraldehyde 3-phosphate dehydrogenase-S, a sperm-specific glycolytic enzyme, is required for sperm motility and male fertility. Proc. Natl. Acad. Sci. U. S. A. 101:16501-16506.

102.Welch, J.E., Barbee, R.R., Magyar, P.L., Bunch, D.O., and O'Brien, D.A. 2006. Expression of the spermatogenic cell-specific glyceraldehyde 3-phosphate dehydrogenase (GAPDS) in rat testis. Mol. Reprod. Dev. 73:1052-1060.

103. Ren, D., et al. 2001. A sperm channel required for sperm motility and male fertility. Nature. 413:603-609.

104.Jin, J.L., et al. 2005. Catsper3 and catsper4 encode two cation channel-like proteins exclusively expressed in the testis. Biol. Reprod. 73:1235-1242.

105.Qi, H., et al. 2007. All four CatSper channel proteins are required for male fertility and sperm cell hyperactivated motility. Proc. Natl. Acad. Sci. U. S. A. 104:1219-1223

106.Xia, J., Reigada, D., Mitchell, C.H., and Ren, D. 2007. CATSPER channel-mediated $\mathrm{Ca}^{++}$entry into mouse sperm triggers a tail-to-head propagation. Biol. Reprod. 77:551-559.

107.Carlson, A.E., et al. 2003. CatSper1 required for evoked $\mathrm{Ca} 2+$ entry and control of flagellar function in sperm. Proc. Natl. Acad. Sci. U. S. A. 100:14864-14868.

108. Quill, T.A., et al. 2003. Hyperactivted sperm motility driven by CatSper 2 is required for fertilization. Proc. Natl. Acad. Sci. U. S. A. 100:14869-14874.

109.Jin, J., et al. 2007. CatSper3 and Catsper4 are essential for sperm hyperactivated motility and male fertility in the mouse. Biol. Reprod. 77:37-44.

110.Nikpoor, P., Mowla, S.J., Movahedin, M., Ziaee, S.A., and Tiraihi, T. 2004. CatSper gene expression in postnatal development of mouse testis and in subfertile men with deficient sperm motility. Hum. Reprod. 19:124-128.

111.Spehr, M., et al. 2003. Identification of a testicular odorant receptor mediating human sperm chemotaxis. Science. 299:2054-2058.

112.Harper, M.J. 1973. Stimulation of sperm movement from the isthmus to the site of fertilization in the rabbit oviduct. Biol. Reprod. 8:369-377.

113.Wassarman, P.M. 1999. Mammalian fertilization: molecular aspects of gamete adhesion, exocytosis, and fusion. Cell. 96:175-183.

114.Hardy, D.M. 2002. Fertilization. Academic Press. San Diego, California, USA. 427 pp.

115.Primakoff, P., and Myles, D.G. 2002. Penetration, adhesion, and fusion in mammalian sperm-egg interaction. Science. 296:2183-2185.

116.Sobrero, A.J., and MacLeod, J. 1962. The immediate postcoital test. Fertil. Steril. 13:184-189.

117. Lilja, H., and Lundwall, A. 1992. Molecular cloning of epididymal and seminal vesicular transcripts encoding a semenogelin-related protein. Proc. Natl. Acad. Sci. U. S. A. 89:4559-4563.

118.Lilja, H. 1985. A kallikrein-like serine protease in prostatic fluid cleaves the prdominant seminal vesicle protein. J. Clin. Invest. 76:1899-1903.

119.Wang, Z., Widgren, E.E., Richardson, E.T., and O'Rand, M.G. 2007. Eppin: a molecular strategy for male contraception. Soc. Reprod. Fertil. Suppl. 65:535-542.

120.Wang, Z., Widgren, E.E., Richardson, R.T., and O'Rand, M.G. 2007. Characterization of an eppin protein complex from human sperm and spermatozoa. Biol. Reprod. 77:476-484.

121. O'Rand, M.G., Widgren, E.E., Wang, Z., and Richardson, R.T. 2006. Eppin: an effective target for male contraception. Mol. Cell. Endocrinol. 250:157-162.

122.Doncel, G.F. 2006. Exploiting common targets in human fertilization and HIV infection: development of novel contraceptive microbicides. Hum. 
Reprod. Update. 12:103-117.

123.Wong,Y.L., et al. 2002. A structure-activity study of spermicidal and anti-HIV properties of hydroxylated cationic surfactants. Bioorg. Med. Chem. 10:3599-3608

124.Hughes, L.M., Griffith, R., and Aitken, R.J. 2007. The search for a topical dual action spermicide/ microbicide. Curr. Med. Chem. 14:775-786.

125.Ghosh, D., De, P., and Sengupta, J. 1994. Luteal phase ovarian estrogen is not essential for implantation and maintenance of pregnancy from surrogate embryo transfer in the rhesus monkey. Hum. Reprod. 9:629-637.

126. Ortiz, M.E., et al. 2007. Progesterone, but not luteal estrogen, is required for the establishment of pregnancy in the new world monkey Cebus apella. Am.J. Primatol. 69:1131-1140.

127. Kovacs, L., et al. 1984. Termination of very early pregnancy by RU486 - an antiprogestational compound. Contraception. 29:399-410.

128.Swahn, M.L., Bygdeman, M., and Gemzell, K. 1994. Anti-conceptive potential of antiprogestin RU486 (mifepristone). In Current Concepts in Fertility Regulation and Reproduction. C.P. Puri and P.F.A. Van Look, editors. Wiley Eastern Ltd. New York, New York, USA. 76-82.

129.Baird, D.T., et al. 2003. Mifepristone: a novel estrogen-free daily contraceptive pill. Steroids. 68:1099-2105.

130. Chabbert-Buffet, N., Pintiaux-Kairis, A., Bouchard, P., and VA2914 Study Group. 2007. Effects of the progesterone receptor modulator VA2914 in a continuous low dose on the hypothalamic-pituitaryovarian axis and endometrium in normal women: a prospective, randomized, placebo controlled trial. J. Clin. Endocrinol. Metab. 92:3582-3589.

131. Carson, D.D., et al. 2002. Changes in gene expression during the early to mid-luteal (receptive phase) transition in human endometrium detected by high-density microarray screening. Mol. Hum. Reprod. 8:871-879.

132.Kao, L.C., et al. 2002. Global gene profiling in human endometrium during the window of implantation. Endocrinology. 143:2119-2138.

133. Martin, J., et al. 2002. Human endometrial receptivity: gene regulation. J. Reprod. Immunol. 55:131-139.

134. Borthwick, J.M., et al. 2003. Determination of the transcript profile of human endometrium. Mol. Hum. Reprod. 9:19-33.

135. Riesewijk, A., et al. 2003. Gene expression profiling of human endometrial receptivity on days $\mathrm{LH}+2$ versus $\mathrm{LH}+7$ by microarray technology. Mol. Hum. Reprod. 9:253-264.

136.Talbi, S., et al. 2006. Molecular phenotyping of human endometrium distinguishes menstrual cycle phases and underlying biological processes in normo-ovulatory women. Endocrinology. 147:1094-1096.

137. Catalano, R.D., et al. 2007. Mifepristone induced progesterone withdrawal reveals novel regulatory pathways in human endometrium. Mol. Hum. Reprod. 13:641-654.

138. Sherwin, R., Catalano, R., and Sharkey, A.M. 2006 Large-scale gene expression studies of the endometrium: what have we learnt? Reproduction. 132:1-10.

139.Horcajadas, J.A., Pellicer, A., and Simón, C. 2007. Wide genomic analysis of human endometrial receptivity: new times, new opportunities. Hum. Reprod. Update. 13:77-86.

140. Bhatt, H., Brunet L.J., and Stewart, C.L. 1991. Uterine expression of leukemia inhibitory factor coincides with the onset of blastocyst implantation. Proc. Natl. Acad. Sci. U. S. A. 88:11408-11412.

141.Stewart, C.L., et al. 1992. Blastocyst implantation depends on maternal expression of leukemia inhibitory factor. Nature. 359:76-79.

142.Yang, Z.M., Chen, D.-B., Le, S.-P., and Harper,
M.J.K. 1996. Differential hormonal regulation of leukemia inhibitory factor (LIF) in rabbit and mouse uterus. Mol. Reprod. Dev. 43:470-476.

143. Kojima, K., et al. 1994. Expression of leukemia inhibitory factor in human endometrium and placenta. Biol. Reprod. 50:882-887.

144.Charnock-Jones, D.S., Sharkey, A.M., Fenwick, P., and Smith, S.K. 1994. Leukaemia inhibitory factor mRNA concentration peaks in human endometrium at the time of implantation and the blastocyst contains mRNA for the receptor at this time. J. Reprod. Fertil. 101:421-426.

145.Gearing, D.P., et al. 1992. The IL-6 signal transducer gp130: an oncostatin $M$ receptor and affinity converter for the LIF receptor. Science. 255:1434-1437.

146. Ghosh, D., Najwa, A.R., and Sengupta, J. 2006. In vitro action of leukemia inhibitory factor (LIF) on mid-secretory stage endometrial stromal cells collected from hormone-stimulated, ovariectomized monkey and maintained in three-dimensional primary culture. Indian J. Physiol. Pharmacol. 50:355-366.

147. Hirano, T., Matsuda, T., and Nakajima, K. 1994. Signal transduction through gp130 that is shared among the receptors for the interleukin 6 related cytokine subfamily. Stem Cells. 12:262-277.

148. Ware, C.B., et al. 1995. Targeted disruption of the low-affinity leukemia inhibitory factor receptor gene causes placental, skeletal, neural and metabolic defects and results in perinatal death. Development. 121:1282-1299.

149.Yue, Z.-P., et al. 2000. Leukemia inhibitory factor, leukemia inhibitory factor receptor and gp130 in rhesus monkey uterus during menstrual cycle and early pregnancy. Biol. Reprod. 63:508-512.

150.Sengupta, J., Parameswaran, G.L., Lalitkumar, P.G., Najwa, A.R., and Ghosh, D. 2006. Monoclonal anti-leukemia inhibitory factor antibody inhibits blastocyst implantation in the rhesus monkey. Contraception. 74:419-425.

151.Fairlie, W.D., et al. 2004. Affinity maturation of leukemia inhibitory factor and conversion to potent antagonists of signaling. J. Biol. Chem. 279:2125-2134.

152. White, C.A., et al. 2007. Blocking LIF action in the uterus by using a PEGylated antagonist prevents implantation: a nonhormonal contraceptive strategy. Proc. Natl. Acad. Sci. U. S. A. 104:19357-19362.

153. Robb, L., et al. 1998. Infertility in female mice lacking the receptor for interleukin 11 is due to a defective uterine response to implantation. Nat. Med. 4:303-308

154.Dimitriadis, E., et al. 2003. IL-11 and IL-11R $\alpha$ immunolocalisation at primate implantation sites supports a role for IL-11 in placentation and fetal development. Reprod. Biol. Endocrinol. 1:34.

155.Dimitriadis, E., et al. 2006. Interleukin-11, IL-11 receptor $\alpha$ and leukemia inhibitory factor are dysregulated in endometrium of infertile women with endometriosis during the implantation window. J. Reprod. Immunol. 69:53-64.

156.Bao, L., et al. 2006. The role of imterleukin-11 in pregnancy involves up-regulation of $\alpha 2$-macroglobulin gene through janus kinase 2-signal transducer and activator of transcription pathway 3 in the decidua. Mol. Endocrinol. 20:3240-3250.

157. Dimitriadis, E., Stoikos, C., Tan, Y.L., and Salamonsen, L.A. 2006. Interleukin 11 signaling components signal transducer activator of transcription 3 (STAT3) and suppressor of cytokine signaling (SOCS3) regulate human endometrial stromal cell differentiation. Endocrinology. 147:3809-3817.

158.Malik, N.M., et al. 2001. Leptin requirements for conception, implantation, and gestation in the mouse. Endocrinology. 142:5198-5202.

159.González, R.R., et al. 2000. Leptin and leptin receptor are expressed in the human endometrium and endometrial leptin secretion is regulated by the human blastocyst. J. Clin. Endocrinol. Metab. 85:4883-4888

160.Gonzalez, R.R., et al. 2004. Leptin-induced increase in leukemia inhibitory factor and its receptor by human endometrium is partially mediated by interleukin 1 receptor signaling. Endocrinology. 145:3850-3857.

161.Tanaka, T., Utsunomiya, T., Bai, T., Nakajima, S., and Umesaki, N. 2003. Leptin inhibits decidualization and enhances cell viability of normal endometrial stromal cells. Int. J. Mol. Med. 12:95-98.

162.Gonzalez, R.R., and Leavis, P.C. 2003. A peptide derived from the human leptin molecule is a potent inhibitor of the leptin receptor function in rabbit endometrial cells. Endocrine. 21:185-195.

163.Ramos, M.P., Rueda, B.R., Leavis, P.C., and Gonzalez, R.R. 2005. Leptin serves as an upstream activator of an obligatory signaling cascade in the embryo-implantation process. Endocrinology. 146:694-701.

164.Gonzalez, R.R. 2006. Blockade of endometrial leptin signaling: a new strategy for the development of contraceptive drugs. Paper presented at the $8^{\circ}$ Congreso de la Sociedad Española de Contracepción. Revista Oficial de la Sociedad Española de Fertilidad. 44-48.

165.Gonzalez, R.R., et al. 2007. Emergency contraception potential of leptin signaling inhibition in a mouse model. Fertil. Steril. 88(Suppl. 1):S52.

166.Nie, G., Findlay, J.K., and Salamonsen, L.A. 2005. Identification of novel endometrial targets for contraception. Contraception. 71:272-281.

167.Nie, G., Wang, M., Liu, Y.X., Findlay, J.K., and Salamonsen, L.A. 2005. Inhibiting uterine PC6 blocks embryo implantation: an obligatory role for a proprotein convertase in fertility. Biol. Reprod. 72:1029-1036.

168.Freyer, C., Kilpatrick, L.M., Salamonsen, L.A., and Nie, G. 2007. Pro-protein convertases (PCs) other than PC6 are not tightly regulated for implantation in the human endometrium. Reproduction. 133:1189-1193.

169.Fugere, M., Appel, J., Houghten, R.A., Lindberg, I., and Day, R. 2007. Short polybasic peptide sequences are potent inhibitors of PC5/6 and PC7: Use of positional scanning-synthetic peptide combinatorial libraries as a tool for the optimization of inhibitory sequences. Mol. Pharmacol. 71:323-332.

170. Dhawan, L., et al. 2000. Anti-nidatory effect of vaginally administered (Ala8,13,18)-magainin II amide in the rhesus monkey. Contraception. 62:39-43.

171.Cancel, A.M., et al. 2006. A one-year neonatal mouse carcinogenesis study of quinacrine dihydrochloride. Int. J. Toxicol. 25:109-118.

172.Family Health International Reproductive Health. 2007. FHI position on studies and utilization of quinacrine for sterilization. http://www.fhi.org/ en/RH/Pubs/factsheets/quinacrine.htm.

173.PATH Technology Solutions for Global Health. SILCS diaphragm. http://www.path.org/files/TS_ update_silcs.pdf.

174.Schwartz, J.L., et al. 2006. SILCS diaphragm: Postcoital testing (PCT) of a new single size contraceptive diaphragm. Paper presented at American College of Obstetricians and Gynecologists' 54th Annual Clinical Meeting (ACM). May 6-10. Washington, DC, USA. 12S.

175.Olmsted, S.S., Dubin, N.H., Cone, R.A., and Moench, T.R. 2000. The rate at which human sperm are immobilized and killed by mild acidity. Fertil. Steril. 73:687-693.

176.Barnhart, K.T., Higgins, J.E., Mackay, H.T., Blithe, D.L., and Moench, T.R. 2006. BufferGel with diaphragm found to be an effective contraceptive in two Phase II/III trials. Paper presented at Microbicides 2006 Conference. April 23-26. Cape Town, South Africa. Abstract OB22. 